\title{
MOVING TOWARD PUBLIC ARCHAEOLOGY IN THE NEJAPA VALLEY OF OAXACA, MEXICO*
}

\author{
HACIA UNA ARQUEOLOGÍA PÚBLICA EN EL VALLE DE NEJAPA, \\ OAXACA, MÉXICO
}

\author{
Elizabeth Konwest ${ }^{1}$ and Stacie M. King ${ }^{1}$
}

\begin{abstract}
Starting any new archaeological project comes with difficult challenges and gratifying rewards. This is especially true for a project that seeks to incorporate public archaeology from its very inception. The Proyecto Arqueológico Nejapa y Tavela was initiated in 2007 by Stacie M. King in an area of Oaxaca without previous formal archaeological work. This paper seeks to explore the various methods we have used to incorporate a public component from the beginning of the project until the present. Public archaeology was conducted in the Nejapa Valley in the communities of Nejapa de Madero and Santa Ana Tavela, which vary in location within the valley, size, access to resources, and concerns among community members. The two towns also have different systems of land tenure that we propose is connected to different levels of local interest and investment in the practice and results of archaeological research. Our initial public archaeology methods included public talks, participation in local events, and the presentation of framed posters about archaeological findings to each town. We discuss the outcomes of these initial efforts, outline more recent and more successful approaches, and discuss our plans to include a community-based research component.
\end{abstract}

Key words: Public archaeology, community-based research, Oaxaca, Mexico.

El inicio de cualquier nuevo proyecto arqueológico lleva consigo desafíos difíciles y recompensas gratificantes. Esto es especialmente válido para proyectos que buscan incorporar arqueología pública desde sus comienzos. El Proyecto Arqueológico Nejapa y Tavela fue iniciado en 2007 por Stacie M. King en una región de Oaxaca que no había sido estudiada previamente. Este artículo explora los métodos que usamos para incorporar a este proyecto los componentes de una arqueología pública, desde el principio hasta el presente. Esto fue realizado entre las comunidades de Madero y Santa Ana Tavela ubicadas en distintas localidades del valle de Nejapa, por lo que presentan diferencias en tamaño de población, acceso a recursos, como así también en las preocupaciones entre los miembros de las comunidades. Las dos localidades presentan sistemas distintos de tenencia de la tierra que a nuestro juicio están relacionados a diferencias en el nivel de interés y la inversión en la práctica y los resultados de la investigación arqueológica. Los métodos de la arqueología pública al principio incluyeron conferencias públicas, participación en eventos locales y la presentación de afiches enmarcados en los hallazgos arqueológicos. Se discuten los éxitos y las fallas de esta iniciativa inicial de arqueología pública. Se detallan nuestros esfuerzos más recientes y exitosos y presentamos los planes futuros para desarrollar una investigación que incluya a la comunidad.

Palabras claves: arqueología pública, investigaciones basadas en la comunidad, Oaxaca, México.

Doing public archaeology and employing community-based methods are no longer viewed as novel activities in archaeology (Kerber 2006; Little 2002). However, specific methods and frameworks for incorporating public archaeology are not part of the canon of methods that all archaeologists employ. As such, it is important for archaeologists engaging in this type of work to communicate both the successes and the failures. In this article, we focus on the Proyecto Arqueológico Nejapa y Tavela (Nejapa and Tavela Archaeological Project, or PANT) and discuss both the challenges and the gratifying rewards that we have experienced doing public archaeology. We explore the various methods we have used to incorporate a public component from the beginning of the project and, as this is an ongoing project, we also discuss some of our more recent -and more successful- efforts. Lastly, we detail our plans for future work, which will incorporate more explicitly framed community-based collaborative research.

Stacie King began the PANT in 2007 to explore a little studied region in southeastern Oaxaca, Mexico that lies on a long-standing trade route between

* Artículo seleccionado del conjunto de ponencias presentadas en el Simposio Shifting from Object-centered Research to People-focused Application: Current Approaches to Public Archaeology from Latin America and the Caribbean, realizado en el marco de la 75 reunión anual de la Sociedad de Arqueología Americana, Saint Louis, Missouri, EUA, abril 2010. Este manuscrito fue evaluado por investigadores externos y editado por Reiko Ishihara-Brito y Cameron Griffith, en su calidad de editores invitados de la Revista.

1 Department of Anthropology, Indiana University, Bloomington, Student Building 130, 701 E. Kirkwood Avenue, Bloomington, IN 47405-7100, USA. ekonwest@indiana.edu; kingsm@indiana.edu 


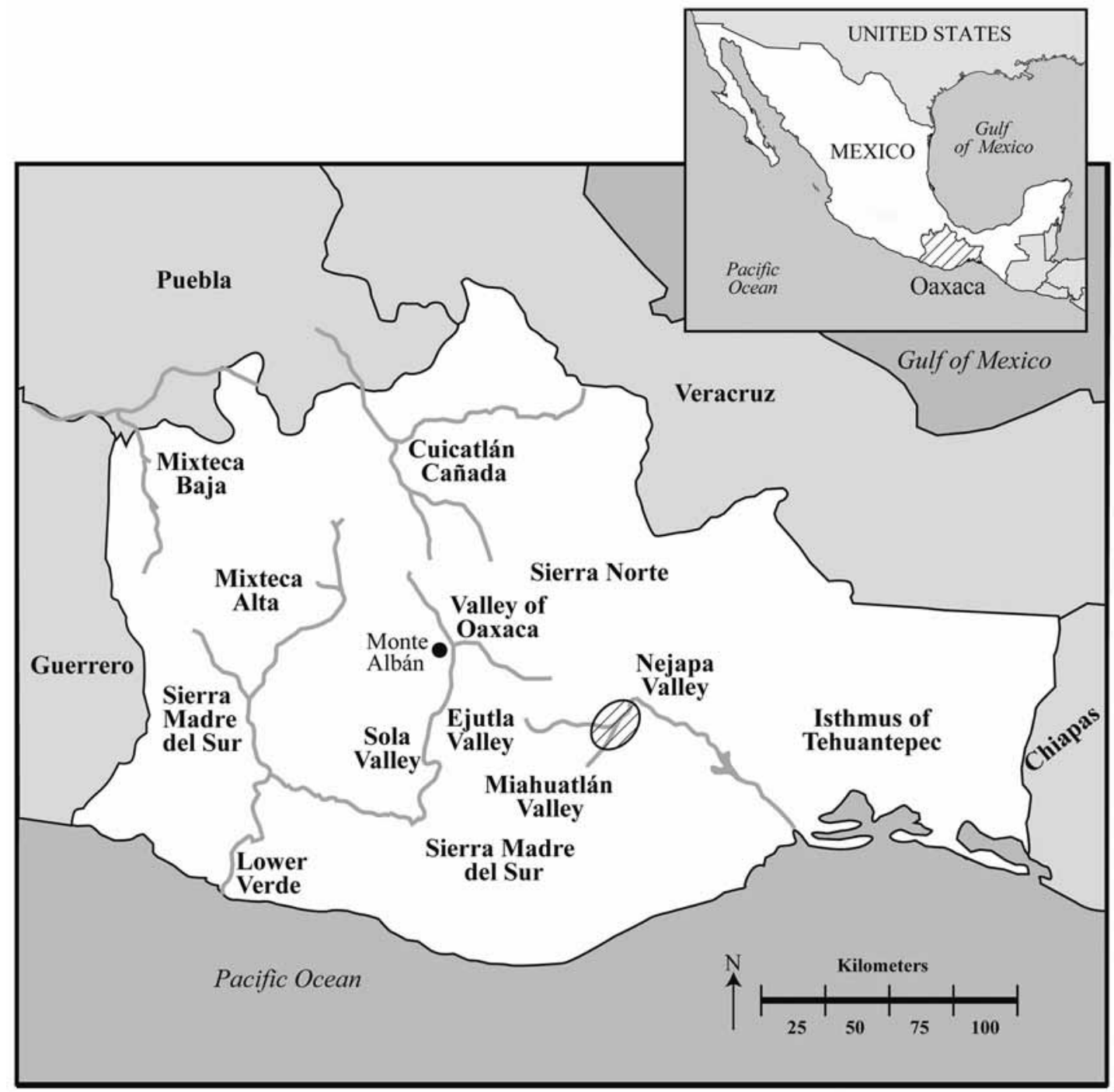

Figure 1. Map showing location of the Valley of Nejapa within Oaxaca, Mexico.

Mapa de ubicación del valle de Nejapa en Oaxaca, México.

the coast and the highlands (Figure 1). The projec aims to better understand the long-term history and complex social and political relationships that existed between multiethnic local residents and foreign migrants, traders, and militaries. Although King's initial plan was to focus on prehispanic settlements located in the agriculturally rich valley bottomlands, she quickly expanded the project's spatial and temporal focus after seeing that nearly half of the recorded archaeological sites were located in the surrounding mountains and some postdated the arrival of the Spanish to Mexico. The first field season in 2007 included initial archaeological reconnaissance and meeting with local community members and leaders to discuss future research. In 2008, King returned to the region to conduct oral history interviews with community members that had lived and worked in the largest ex-hacienda ${ }^{1}$ and continued to build working relationships with local community leaders and government authorities. In 2009, King returned to the region for the initial fourmonth field season of reconnaissance, systematic survey, and test pitting on lands belonging to two municipalities, Nejapa de Madero and Santa Ana Tavela (Figure 2). Konwest joined the project in 2009 as a member of the field and laboratory crew. In addition to the survey, excavation, and analysis of materials collected in the field from January to 


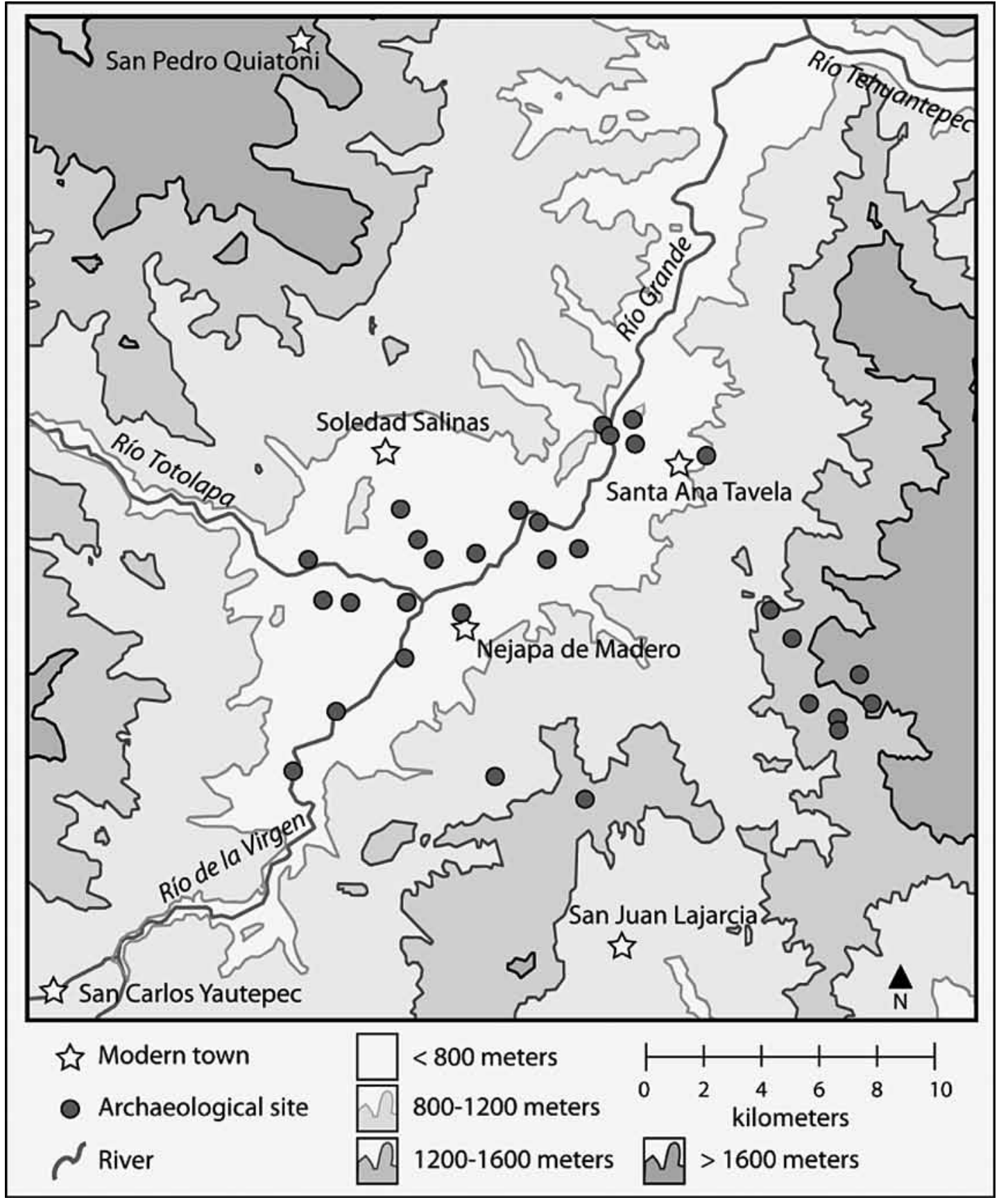

Figure 2. Valley of Nejapa study region.

Región del estudio, valle de Nejapa.

April 2009, King also documented several collections of artifacts that were being held by both private individuals and the municipal government. In July 2009, King and Konwest (hereafter, we) returned to Nejapa and Tavela to present to each town framed, large format maps showing the locations of all of the archaeological sites we had recorded and to give public talks about the results of our research. We purposely timed our visit to coincide with the each of the town's annual patron saint festivals to ensure that we could reach as many residents and visitors as possible and increase the visibility of our research. 


\section{Doing Public Archaeology}

Many archaeologists working across the globe and in Mexico now engage in public outreach and education. The Society for American Archaeology, the largest professional organization for working archaeologists, has named public education and outreach as an important disciplinary ethical imperative. In the SAA's Principles of Archaeological Ethics, Principle Number Four on Public Education and Outreach states: "Archaeologists should reach out to, and participate in cooperative efforts with others interested in the archaeological record with the aim of improving the preservation, protection, and interpretation of the record..." (Society for American Archaeology 1996). This commitment is also stipulated in the codes and principles of many other archaeological organizations, including the Canadian Archaeological Association and the Society for Historical Archaeology ${ }^{2}$. We believe that this principle should be incorporated into the life of an archaeological project at many, if not all, stages.

Doing public archaeology is thus becoming a global phenomenon and many archaeologists agree that engaging with the public can improve the quality of the research and have lasting benefits for the communities involved. In the 2002 volume Public Benefits of Archaeology, Barbara Little writes that community leaders find that archaeology can help people build links in the present as well as to the past. Jeremy Sabloff (2008) argues that archaeology has the potential to aid in solving specific problems communities may be facing such as growing landfills in the United States and land fertility in Peru and Bolivia. Archaeologists working in varied countries and contexts share the rewards, challenges and results of partnering with local communities (Derry and Malloy 2003). For example, researchers in Queensland, Australia collaborated with the Waanyi Women's History Committee to achieve various joint goals including recording cultural and historical resources and training local women to record oral histories (Smith et al. 2003). They conclude that sharing control of the project was an essential step in the success of their collaboration. Likewise, Moser et al. (2002) show that their collaborative work on public presentations, oral histories, and controlled merchandising in Quseir, Egypt were necessary ingredients in all parts of the archaeological research process.
Definitions of public archaeology are conceived of both narrowly and broadly. For example, in the United States, some still use the term public archaeology as an interchangeable term for cultural resource management (Archaeological Institute of America 2006) and the phrase first appears in print used in this manner during the 1970s. On the opposite end of the spectrum, public archaeology is sometimes interpreted as archaeology with "direct public engagement" (Merriman 2004:4). In this article, we use public archaeology as a term for archaeology with public engagement and benefit. However, there are differing opinions on the definition of benefits. Archaeologists should benefit from public engagement, since public archaeology and education will hopefully increase public stewardship (Society for American Archaeology 1996), but the community should also benefit. Scientific practice should be decolonized and made accessible to outside participants and projects should produce positive (or at least non-harmful) results for local peoples (Nicholas and Hollowell 2007). We believe that most archaeologists, including ourselves, envision public archaeology will have benefits for both the archaeological research and the various communities in which we work.

In Mexico, many archaeologists have worked closely with the public. For example, in the Maya region, archaeologists working at Chunchucmil have documented their attempt to put together a community museum based on the results of the archaeological research at that site (Ardren 2002). Community museums in Oaxaca have both enhanced indigenous people's pride in heritage and have increased local involvement in the stewardship of archaeological resources (Hoobler 2006). Elsewhere in Oaxaca, Zborover (2007) has engaged in public archaeology by incorporating local people into the research process, including inviting children to visit an archaeological excavation located on the grounds of the local school. Robles Garcia (2000) comprehensively discusses her work engaging with local communities at the sites of Monte Albán and Mitla, both in Oaxaca. Her report identifies issues and stakeholders that all archaeologists should consider before proposing an archaeological project and specifically refers to those archaeologists, like ourselves, who wish to engage in public archaeology in Mexico. Robles Garcia argues that the key stakeholders in Mexican archaeology are the archaeologists, the government, 
and local communities, each of which will have differing and sometimes competing ideas on how to protect and study archaeological materials. Further, each of these groups, institutions, and communities are internally subdivided, which complicates the implementation of archaeological research.

\section{Community Concerns}

Robles Garcia (2000) notes that one of the major challenges in working with communities in Mexico (and in Oaxaca, specifically) is the complexity of the Mexican land tenure system. In Mexico, before beginning any archaeological project, it is important to understand the land tenure system of the different communities where one plans to undertake research. This task is notoriously difficult since specific land tenure practices vary across the nation, from state to state, and from municipality to municipality. In general, in Oaxaca, most land falls into four categories: land can be communitycontrolled (comunal), privately owned (pequeñas propiedades, or small properties), federally owned (federal), or controlled by an ejido. Ejido land is controlled by a legally-recognized collective of shared property owners coordinated by the Federal Secretary of Agrarian Reform (Secretaría de la Reforma Agraria). However, regardless of the land tenure system in place, Mexican land laws all stipulate that archaeological monuments and artifacts are the property of the Mexican nation (Robles Garcia 2000).

The land controlled by Santa Ana Tavela is composed entirely of communal lands, controlled by adult male and female comuneros. Becoming a comunero is based, in part, on birth, and in part, on use of the land; most of Tavela's comuneros were born in Tavela, but one can become a comunero through in-migration as an adult. In Nejapa de Madero, however, there is a mix of different types of land tenure; some lands are communal, large tracts belong to the ejido, and still other parcels are private. The different land tenure systems in both of these communities were both challenges and opportunities for conducting public archaeology in the region. Land tenure practices were important considerations in planning archaeological fieldwork, which had clear implications for gaining permissions and for organizing and planning our public talks.
Due to the variety of land tenure systems and governing bodies, it was important to approach the right people to request permission and, as it turns out, attempt to visit them in the right order. In Tavela, we contacted the municipal government first and were then directed to meet with the Comisaría de Bienes Comunales, the committee charged with managing any affairs having to do with communal land. Formal permission, however, was not immediately granted. For this, we had to wait four weeks until a scheduled town assembly, during which we were given a few minutes to publicly present our project goals to the group that had gathered. After answering questions, we were excused and all town members voted on whether or not we would be allowed to work in the community. This process took approximately one hour and there were several community members who asked pointed questions and seemed initially distrustful of our motives and of archaeology in general. However, the results of the vote were positive, quorum was achieved, and a majority vote in our favor meant that we were allowed to proceed with our research. After that, we regularly communicated with both groups of authorities, but always made sure to approach Comisaría de Bienes Comunales first in order to show respect for their control of all matters related to lands. Talking with both groups was not just a move to check various authorities off of a list, but it was also an important step in making connections with multiple community stakeholders and acknowledging the division of authority in town and land matters. Frequent meetings and status reports helped us to maintain and strengthen those connections.

In Nejapa, the process was much easier and we received permission to work within a matter of minutes. We visited the office of the municipal president, explained what the project was about, and showed the president our federal and state level permission letters from the National Institute of Anthropology and History (Instituto Nacional de Antropología e Historia, or INAH). With the president's signature and seal, we had all that we needed to complete the research, and were able to start work the next day. In Nejapa, we continued to work through the municipal government for the duration of the project even though we worked with many individual ejido members and surveyed within ejido lands.

The differences of approach for each community were based not only on land tenure systems 
but also on internal town politics, the size of the municipality, and the location of our residence. Nejapa is a much larger municipality in both area and population, with approximately 7,930 residents divided among approximately 30 different subject towns (agencias) and isolated ranches, with elected municipal leaders that stay in office for three years (García García 1998). Nejapa rarely holds town assemblies to discuss communal matters and leaders are entrusted with maintaining the day-to-day operation of the town, managing projects, and making decisions. Our home and base of operations, however, was located in Santa Ana Tavela, a community with less than a fourth of the amount of land of Nejapa. All approximately 1,100 residents of Santa Ana Tavela live together in one town. We think that our decision to live in Tavela helped in our public request for permission and was crucial to the positive outcome. We came to understand both of these systems of government through talking with many people, visiting local government officials -in their offices and in their homes- and asking many questions. We have learned that this process can take a considerable amount of time and patience, but it is time well spent.

As most archaeologists would agree, it is important to remind ourselves that communities are not homogenous. Even in a small town like Tavela, different actors may have multiple motives for wanting to engage with archaeology. Trying to figure out the key players and each person's varied interests and memberships is an important first step in understanding community dynamics (Pyburn 2009). Robles Garcia (2000) mentions various motives that people in Oaxaca tend to have with respect to archaeological projects, including economic interests, concerns over land rights, and interest in protecting places believed to be sacred. In addition, the results of archaeological investigation are inherently interesting to people who have curiosity about the past. Robles Garcia notes that archaeologists working in Mexico also have other stakeholders to consider beyond the local communities. In Oaxaca, these stakeholders include the INAH and the Centro INAH Oaxaca, the Mexican bodies of government that manage all archaeological work, including protection, conservation, investigation, and public outreach. As project members working in Mexico, we carefully adhere to INAH policy, mindful of the political framework at the federal, state, and local levels.

\section{Early Outreach Efforts}

After the conclusion of the spring 2009 field season, we returned in July and August to conduct archival work in Oaxaca City, to continue our laboratory analysis of archaeological materials, and to present preliminary results of our work in a public forum in Nejapa de Madero and Santa Ana Tavela. The summer trip was timed to coincide with the feast days of both Nejapa de Madero and Santa Ana Tavela's patron saints. We felt that this was a good time to return and participate in important community events. However, due to our commitment to various political bodies and the flurry of activities that correspond with the celebrations, our timing was ultimately both a challenge and a reward. Our presence at these community events was an important first step in showing our continuing commitment to each town. Returning during the feast days helped to maintain the momentum of collaboration and helped to show our respect to the many individuals that had invited us to be guests at the fiesta. In addition, the feast days attract many former community members and extended family members and the population swells during this time. Many visitors approached us to ask us about our work and expressed both surprise and interest at the wealth of archaeological remains in the region. Our presence during this time allowed us to engage with people that we otherwise would not have been able to reach.

However, there were some major drawbacks to choosing this time to return. Many town authorities that previously had time to talk and engage with us had increased political and familial obligations. In Nejapa de Madero, we were able to schedule a public talk for the day before the fiesta officially started. Community members were invited via several announcements on the town loudspeaker the day of the event. Approximately 15 community members attended, including people on whose lands we had conducted archaeological work (Figure 3 ). In Tavela, however, members of Comisaría de Bienes Comunales were too busy with the many political and personal obligations for the fiesta and they were not able to meet as a group in order to approve our talk and schedule the event. We therefore were unable to conduct a public talk in this town at this time. The timing of the public talk was important because Comisaría de Bienes Comunales wanted to ensure that our information would be conveyed to 


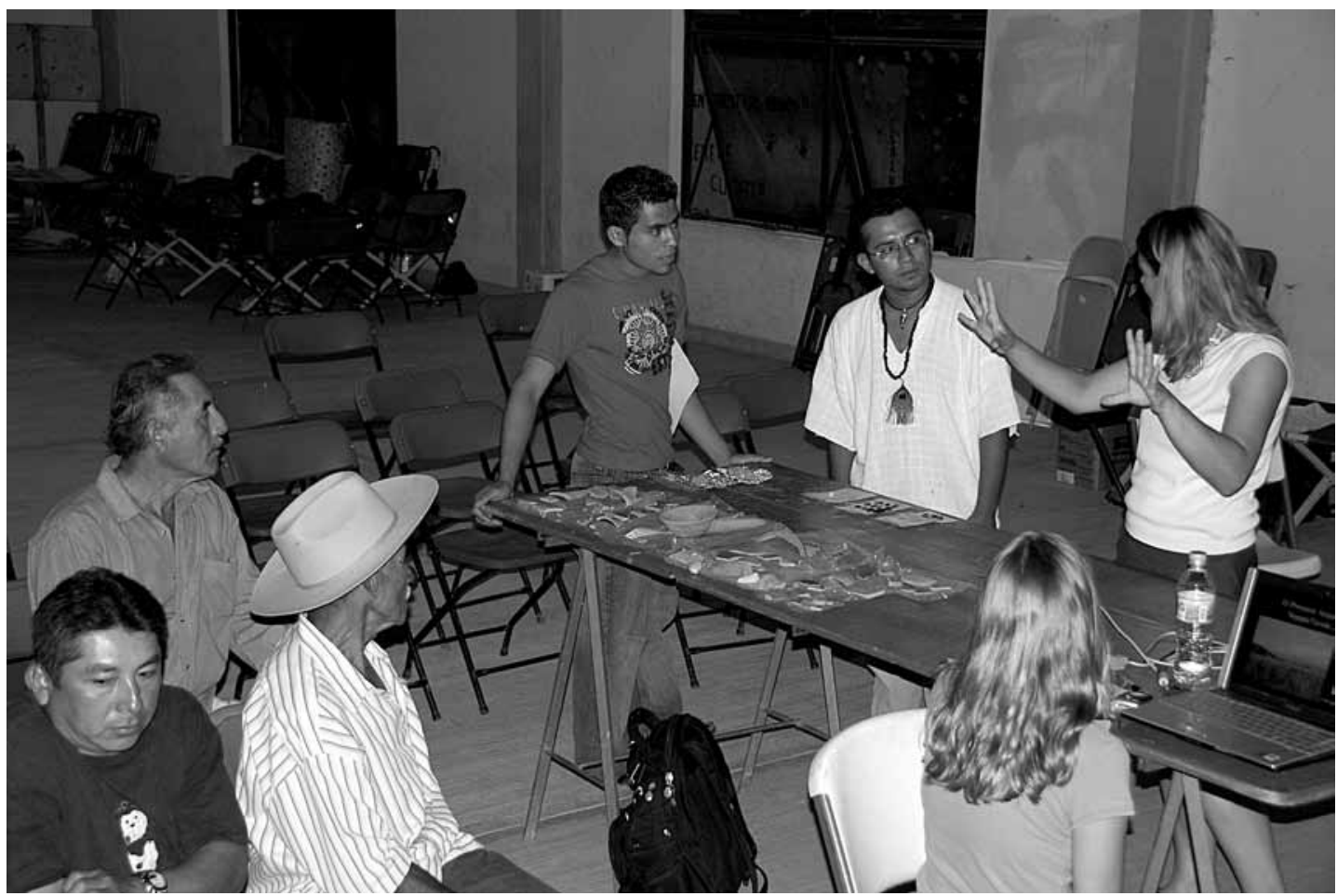

Figure 3. Public talk in Nejapa de Madero, 2009.

Charla pública en Nejapa de Madero, 2009.

as many people as possible in a public, visible and transparent manner, so that no one would become suspicious or accuse us or Comisaría de Bienes Comunales of playing favorites, but ironically, the push for transparency resulted in us not being able to share anything. Due to the framework of working in a grant cycle and working around the academic school schedule, we imagine that many project directors have to make hard decisions about when to spend time in the communities in which they work. In rural Mexico, these constraints are further compounded by limited access to the internet and the necessity of in-person communication for arranging events such as public talks. Our lead time for arranging the talks was extremely limited and presented an additional difficulty.

To counter some of the problems associated with our absence from the community, King designed a poster that was framed and presented to each town at the conclusion of the public talk. The posters featured a map of the respective municipal boundaries with the locations of the known archaeological sites that we were able to visit marked on the map. We produced the maps by incorporating publicly available, official National Institute of Statistics and Geography (Instituto Nacional de Estadística y Geografía, or INEGI) data on municipal boundaries with archaeological data collected in the field in ArcGIS. These maps were tailored for each town and contained information that we thought might be of interest to the community members, including the locations, site boundaries, and names of archaeological sites in the region that would be listed on Mexico's National Register of Archaeological Sites (Registro Público de Sitios Arqueológicos). We thought that the maps would be a good use of time and resources because they could be hung in a public space and would endure after our departure from town. As such, the maps not only communicated results of the previous field season's research, but they would help to remind people of the work we intended to continue in future field seasons.

Upon receiving the maps, however, comments focused almost exclusively on the inaccuracies of the municipal boundaries as recorded by INEGI. The map given to Nejapa, whose municipal boundaries according to INEGI include a much larger territory than the community actually controls, is now 
hanging in a room located in the main government building. In Tavela, because we could not schedule a public talk, we never had a public venue in which to present the map to the town. Instead, we gave it to the president of Comisaría de Bienes Comunales in his office and asked him to share it with the town. Unfortunately, the INEGI municipal boundaries grossly underestimated the lands that belong to Santa Ana Tavela and, not surprisingly, the map has never been displayed. Our maps, therefore, while well intentioned and visually striking, did not have the kind of impact we had hoped they would have. This was another example of public archaeology that upon first glance seemed like it would have a positive impact, but in the end resulted in sending poorly communicated messages with inaccurate data.

\section{Later Outreach Efforts}

Even though our initial attempts at public archaeology may not have been met with enthusiastic responses from all parties, we felt confident that we were moving in the right direction. Although the turnout at the public talk in Nejapa was low, many people approached us during other fiesta events saying they had heard the announcements for the talk on the town loudspeaker and were interested in what we were doing even though they could not attend. They appreciated that there was a talk even if they did not come to listen to it. Those in attendance seemed generally engaged, asking questions and staying afterwards to look at the sample of materials on display. Although our poster maps have been critiqued, this feedback has allowed us to produce better materials and we continue to improve upon them as we receive more helpful criticisms. Subsequent materials developed for display have included more photographs of the people in the field, which have been met with a much more favorable response. Political leaders were also pleased to receive copies of our field report when it was completed in November 2010. We also gave copies of these materials to the public library so that the general public could see the results.

In June 2010, King was able to return to Tavela and deliver a highly successful public talk. About 50 community members were able to attend the lecture, ranging in age from young children to elderly adults. Many attendees were eager to give feedback as well as ask questions and seemed pleased with the project results. In March 2011, permission for a third field season was granted quickly during a town assembly, and many former field laborers and previous government officials spoke favorably about what the project had accomplished. Others raised their hands, not to ask questions, but to add praise for the good work that we are doing in town. Permission in Nejapa was once again granted with a single signature in 2011. Although we did not work much in Nejapa lands during this field season, we remain disheartened that few people have expressed interest in our work or even seem aware of what we are doing.

Ultimately, our greatest realization has been that, like other aspects of archaeology, doing public archaeology is highly contextual. The public outreach activities that are most successful in the United States may not work in Mexico. The successful public outreach activities employed in towns near Oaxaca City may not work in Nejapa or Tavela. For that matter, the educational activities that might work in Nejapa may not be appropriate for Tavela. Part of the reason for the differential success of our activities in Nejapa and Tavela, we suspect, is due to the different land tenure systems. In Tavela, where all land is communally owned, everyone has a vested interest in knowing and understanding the results of our archaeological fieldwork. As a group, community members have been interested in thinking of unique ways they might be able to capitalize on our work and have a renewed sense of appreciation for their lands. Though the initial reception of our presence in Tavela was guarded, ultimately Taveleños seem to have the most interest in the results of our research. In Nejapa, where land tenure systems are more varied and the larger population dictates that more decisions are made directly by the government, there is less obvious community-level interest in our work. Here, we need to explore different methods in public archaeology.

\section{Future Goals}

In the future, we plan on incorporating community-based research methods. In doing community-based research, project members will collaborate with interested community members in both Tavela and Nejapa to discuss ways that archaeologists and locals can partner together to undertake outreach and educational activities. In this way, educational outreach activities will be 
more specifically tailored towards each community's needs and interests. For example, in Tavela, people are interested in keeping archaeological materials in town and creating a small community museum. King has assisted a committee in finding funding sources and grant agencies to which they can apply for money and has put the committee in touch with the directors of the community museum program in Oaxaca. In 2011, we successfully hosted a public exposition during Tavela's annual fiesta in which we displayed artifacts found in local sites as well as a poster with photographs of the various people that have worked with us in the field. The response to the exposition was extremely positive and nearly 300 local community members and their out-oftown guests visited the exposition during the three days it was held (Figure 4). Those in attendance remarked favorably about seeing the materials and were happy to learn new information about the history of the area. For many of them, Tavela is the home of their grandparents or is the place where they were born, so learning about the deep time depth of occupation in the region was eye opening and exciting. Government officials brought their extended family members to the exposition and took pride in showing them the materials that we collected and pointing out specific people from the community in our poster. During the exposition, we had many informal conversations with people who told us about additional areas that might be worth exploring or gave us more information about known archaeological sites. The exhibition allowed for interactive dialogue and demonstrated the benefits of moving beyond a more traditional public talk.

Sonya Atalay (2007:266) notes that doing community-based archaeology is "not an end unto itself" but instead can lead to long term partnerships. We see continued collaborative public archaeology to be an important step in building a long-term sustainable research program in the Nejapa region of Oaxaca. Community-based methods have proven to be rewarding for both communities and archaeologists, and like community museums, they are a major aspect of decolonizing scientific research. Hopefully, such methods will open up exciting avenues for collaborative research in Nejapa Valley for years to come. Our early efforts

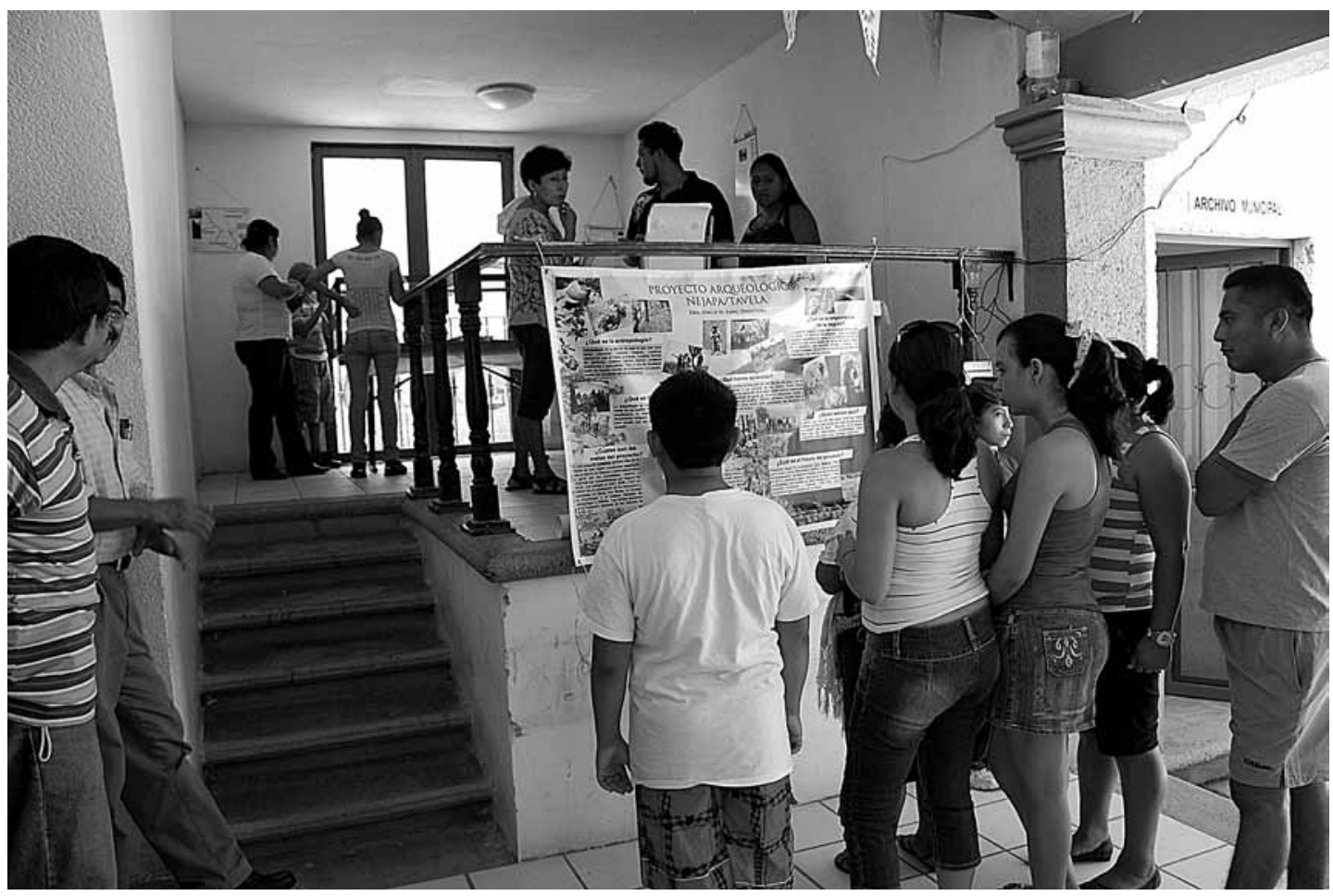

Figure 4. Public exposition in Santa Ana Tavela, 2011.

Exposición pública en Santa Ana Tavela, 2011. 
in public archaeology have expanded into formulating collaborative research questions with interested community members. Already, our plans for future excavations have shifted to include archaeological sites in the valley that community members indicated they were most interested in learning more about. Our current grant proposals were written explicitly with these particular sites in mind.

Overall, our experience incorporating public archaeology from the beginning stages of research has been positive. Although our initial efforts had problems, such as the lackluster timing of the public talks or the troubled reception of the framed maps, they also led to increased visibility and awareness of our research and inspired multiple impassioned conversations. Our continued efforts to communicate and collaborate have been noticed and appreciated. Many people stated that they now have a new appreciation for their past history and for their land, and genuinely thanked us for being there and doing this work. Each attempt at collaboration and public archaeology is a learning experience and has allowed us to grow as archaeologists and become more incorporated into local town life. Incorporating public, community-based archaeology is an essential component of a responsible archaeology that will lead to a mutually beneficial, people-centered research project.
Acknowledgements: First and foremost, we would like to express our appreciation for the people of the Nejapa region, especially the citizens of Nejapa de Madero and Santa Ana Tavela. We would also like to thank Cameron Griffith and Reiko Ishihara-Brito, the organizers of the 2010 Society for American Archaeology symposium, for inviting us to participate and to submit our paper for publication. We also thank fellow team PANT members, the Instituto Nacional de Antropología e Historia, and the Centro INAH Oaxaca. The 2007-2009 research was funded through grants to Stacie King from the New Frontiers in the Arts and Humanities program, the Center for Latin American and Caribbean Studies, the Office of the Vice-Provost for Research, and the College Arts and Humanities Institute, all of Indiana University. In 2011, PANT research was supported through a grant to King from the National Science Foundation (Grant \#1015392). A David C. Skomp Summer Research Award from the Anthropology Department and a Tinker Field Research Grant from the Center for Latin American and Caribbean Studies at Indiana University supported Elizabeth Konwest's participation in the 2009 project. Finally, we thank the outside reviewers and editors of Chungara for their helpful comments and suggestions, but as always, any mistakes or omissions are our own.

\section{References Cited}

Archaeological Institute of America 2006. Federal archaeologist. Archaeology (30 June). www.archaeology.org/online/interviews/ mcmanamon.html (7 September 2011).

Ardren, T. 2002. Conversations about the production of archaeological knowledge and community museums at Chunchucmil and Kochol, Yucatán, México. World Archaeology 34:379-400.

Atalay, S. 2007. Global application of Indigenous Archaeology: Community based participatory research in Turkey. Archaeologies 3:249-270.

Canadian Archaeological Association n.d. Principles of ethical conduct. http://canadianarchaeology.com/caa/about/ethics/ principles-ethical-conduct (27 August 2011).

Derry, L., and M. Malloy (eds.) 2003. Archaeologists and Local Communities: Partners in Exploring the Past. Society for American Archaeology, Washington, D.C.

García García, A. (ed.) 1998. Oaxaca: Distritos, Municipios, Localidades y Habitantes. Angel García García y colaboradores, Oaxaca.

Hoobler, E. 2006. "To take their heritage in their hands": Indigenous self-representation and decolonization in the community museums of Oaxaca, Mexico. The American Indian Quarterly 30(3):441-460.

Kerber, J.E. (ed.) 2006. Cross-Cultural Collaboration: Native Peoples and Archaeology in the Northeastern United States. University of Nebraska Press, Lincoln.

Little, B.J. 2002. Archaeology as shared vision. In Public Benefits of Archaeology, edited by B.J. Little, pp. 3-19. University Press of Florida, Gainesville.

Merriman, N. 2004. Introduction: Diversity and dissonance in public archaeology. In Public archaeology, edited by N. Merriman, pp. 1-19. Routledge, New York.

Moser, S., D. Glazier, J.E. Phillips, L. Nasser el Nemr, M.S. Mousa, R.N. Aiesh, S. Richardson, A. Conner, and M. Seymour 2002. Transforming archaeology through practice: strategies for collaborative archaeology and the Community Archaeology Project at Quseir, Egypt. World Archaeology 34:220-248.

Nicholas, G., and J. Hollowell 2007. Ethical challenges to a postcolonial archaeology: The legacy of scientific colonialism. In Archaeology and capitalism: from ethics to politics, edited by Y. Hamilakis, pp. 243-262. Left Coast Press, Walnut Creek, California. 
Prem, H.J. 1992. Spanish colonization and Indian property in Central Mexico, 1521-1620. Annals of the Association of American Geographers 82(3):444-459.

Pyburn, K.A. 2009. Engaged archaeology: Whose community? Which public? In Global Public Archaeology, edited by A. Matsuda and K. Okamura, pp. 29-41. Springer, New York.

Robles Garcia, N.M. 2000. The management of archaeological resources in Mexico: Oaxaca as a case study. Society for American Archaeology. http://www.saa.org/AbouttheSociety/Publications/ TheManagementofArchaeologicalResourcesinMexi/tabid/1047/ Default.aspx (1 April 2010).

Sabloff, J.A. 2008. Archaeology Matters. Left Coast Press, Walnut Creek, California.

Smith, L., A. Morgan, and A. van der Meer 2003. The Waanyi women's history project: a community partnership project,
Queensland, Australia. In Archaeologists and Local Communities: Partners in Exploring the Past, edited by L. Derry and M. Malloy, pp. 147-165. Society for American Archaeology, Washington, D.C.

Society for American Archaeology 1996. Principles of archaeological ethics (10 April 1996). http://www.saa.org/AbouttheSociety/ PrinciplesofArchaeologicalEthics/tabid/203/Default.aspx. (11 August 2010).

Society for Historical Archaeology 2003. Ethical principles of the Society for Historical Archaeology (21 June 2003). http:// www.sha.org/about/ethics.cfm (27 August 2011).

Zborover, D. 2007. The Chontalpa Historical Archaeology Project, Oaxaca. Final report on file with the Foundation for the Advancement of Mesoamerican Studies, Inc. http://www. famsi.org/reports/05038/index.html (1 April 2010).

\section{Notes}

1 Haciendas are private land estates formed during the colonial period. For more information on their formation and history in Mexico see Prem 1992. An oral historian collects verbal information from groups and individuals about the past.

2 The Canadian Archaeological Association's Principles of Ethical Conduct - Public Education and Outreach: "A fundamental commitment to stewardship is the sharing of knowledge about archaeological topics to a broader public and to enlist public support for stewardship" (Canadian Archaeological Association n.d.).

The Society for Historical Archaeology's Ethical Principles - Principle 7: "Members of the Society for Historical Archaeology encourage education about archaeology, strive to engage citizens in the research process and publicly disseminate the major findings of their research, to the extent compatible with resource protection and legal obligations" (Society for Historical Archaeology 2003). 
